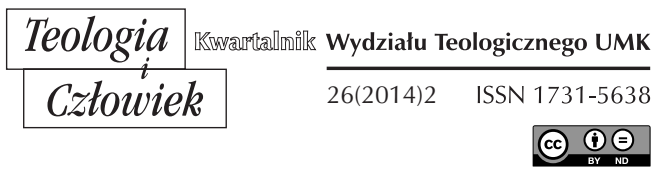

BEATA BILICKA*

TORUŃ

\title{
ZAPOMNIANE KOMPENDIUM?
}

DOI: http://dx.doi.org/10.12775/TiCz.2014.020

W wigilię uroczystości Świętych Apostołów Piotra i Pawła, 28 czerwca 2005 roku, w Sali Klementyńskiej w Watykanie odbyła się, z udziałem Ojca Świętego Benedykta XVI, uroczysta prezentacja Kompendium Katechizmu Kościoła Katolickiego. Jest to pierwsze w historii Kościoła kompendium, które w sposób syntetyczny ukazuje główne zagadnienia wiary katolickiej zawarte w Katechizmie Kościoła Katolickiego ${ }^{1}$. Pojawienie

* Doktor habilitowany nauk teologicznych w zakresie katechetyki. Od 2012 r. kierownik Zakładu Katechetyki Pedagogiki Religii na Wydziale Teologicznym UMK w Toruniu.

${ }^{1} \mathrm{~W}$ tym miejscu warto przypomnieć, że pierwszym jednolitym katechizmem Kościoła katolickiego był, opublikowany w 1566 roku z polecenia Soboru Trydenckiego, Catechismus Romanus, który przez ponad cztery wieki stał się podstawą tworzenia licznych katechizmów lokalnych i niezastąpionym narzędziem duszpasterskim dla kapłanów i katechetów. Katechizm nosił różne tytuły: Katechizm Soboru Trydenckiego, Katechizm Świętego Piusa V, Katechizm dla proboszczów, Katechizm Rzymski; powszechnie przyjął się jednak ten ostatni. Por. Catechismus Romanus seu Catechismus ex Decreto Concilii Tridentini ad Parochos Pii Quinti Pontificis Maximi iussu editus, wyd. P. Rodriguez, Città del Vaticano 1989, s. 24. Więcej na temat Katechizmu Rzymskiego zob. w: B. Bilicka, Katechizmy katolickie XVI wieku, „Teologia i Człowiek” 5 (2007) nr 9, s. 177-196; J. Z. Słowiński, Katechizmy katolickie w jezzyku polskim od XVI do XVIII wieku, Lublin 2005, s. 87-123; D. Kuźmina, Katechizmy Rzeczypospolitej XVI i początku XVII wieku, Warszawa 2002, 
się długo oczekiwanego Kompendium Katechizmu Kościoła Katolickiego wzbudziło wówczas ogromne zainteresowanie nie tylko wiernych, lecz także środków masowego przekazu. Dokument pojawił się bardzo szybko również w Polsce, bo już na początku września 2005 roku. Od tamtego wydarzenia minęło więc kilka lat, a mimo to - jak się wydaje - nie doczekał się właściwej recepcji w polskiej katechezie. Mała liczba publikacji na temat Kompendium², jak również jego marginalne zastosowanie w szkole, skłaniają do podjęcia rozważań na temat wykorzystania Kompendium Katechizmu Katolickiego w nauczaniu religii ${ }^{3}$. Zagadnienie to, mimo upływu lat, nie traci na swojej aktualności, a wręcz przeciwnie - domaga się przypomnienia i popularyzacji.

\section{GENEZA KOMPENDIUM KATECHIZMU KOŚCIOŁA KATOLICKIEGO}

Na potrzebę opracowania Kompendium Katechizmu Kościoła Katolickiego zwrócili uwagę uczestnicy Międzynarodowego Kongresu Katechetycznego, który odbył się w Rzymie w dniach 8-10 października 2002 roku z okazji dziesiątej rocznicy publikacji Katechizmu Kościoła Katolickiego ${ }^{4}$

s. 27-33; M. Rusiecki, Katechizm Rzymski, w: Encyklopedia katolicka, t. VIII, Lublin 2000, kol. 1052-1054; tenże, Przedmiot katechezy potrydenckiej w Polsce (1566-1699), Lublin 1996; T. Gogolewski, Bibliografia polskich przekładów „Katechizmu Rzymskiego”, "Collectanea Theologica" 24 (1953) f. I-IV, s. 266-285.

2 Por. A. Kiciński, Dialog Kościoła z młodymi. Youcat - Katechizm Kościoła Katolickiego dla młodych, „Katecheta” 55 (2011) nr 9, s. 9. Najnowsza Bibliografia katechetyczna wymienia zaledwie 7 artykułów na temat Kompendium KKK, zob. R. Czekalski (opr.), Bibliografia katechetyczna 2001-2010, Warszawa 2012, s. 15-18.

${ }^{3} \mathrm{~W}$ przygotowaniu jest mój artykuł na temat Youcat narzędziem nowej radosnej ewangelizacji.

${ }^{4}$ Więcej na temat Katechizmu Kościota Katolickiego zob. w: J. Ratzinger, Ch. Schönborn, Breve introduzione al Catechismo della Chiesa cattolica, wyd. III, Rzym 2005; J. Królikowski (opr.), Powstanie i znaczenie Katechizmu Kościoła Katolickiego w wypowiedziach papieża Jana Pawta II i kardynała Josepha Ratzingera, Poznań 1997; tenże, Mały przewodnik po Katechizmie Kościoła Katolickiego, Poznań 1996; J. Ratzinger i inni, Wprowadzenie do Katechizmu Kościoła Katolickiego, Warszawa 1994; M. Napieralski, O nowym katechizmie. Wprowadzenie w lekturę Katechizmu Kościoła Katolickiego, Poznań 1994; R. Martinelli (red.), Il Catechismo del Vaticano II. Intoduzione al Catechismo della Chiesa Cattolica, Rzym 1993; S. Pawłowski, Bibliografia Katechizmu Kościoła Katolickiego: cz. I - Teologia w Polsce (1997) nr 49, s. 16-28; cz. II - Teologia w Polsce, (1998) nr 52, s. 39-57; cz. III - Teologia w Polsce, (1998) nr 54, s. 17-32; cz. IV - Teologia w Polsce, (1999) nr 58, s. 18-23. Dalej stosuję skrót: KKK. 
i piątej rocznicy ogłoszenia Dyrektorium ogólnego o katechizacji. Uznając za słuszną propozycję uczestników kongresu dotyczącą opracowania autorytatywnej, pewnej i kompletnej syntezy Katechizmu Kościota Katolickiego, papież Jan Paweł II w liście do kardynała Josepha Ratzingera z dnia 2 lutego 2003 r. poprosił, „aby w porozumieniu z Sekretariatem Stanu zechciał powołać specjalną komisję, której zadaniem będzie przygotowanie Kompendium Katechizmu Kościoła Katolickiego". Wskazał także, że „Kompendium Katechizmu Kościoła Katolickiego powinno zawierać istotne i podstawowe treści wiary Kościoła, sformułowane w sposób zwięzły, z zachowaniem ich kompletności i integralności doktrynalnej, tak by mogło stanowić swego rodzaju vademecum pozwalające wierzącym i niewierzącym jednym spojrzeniem ogarnąć całą panoramę wiary katolickiej. Jego źródłem, wzorem i stałym punktem odniesienia będzie aktualny Katechizm Kościoła Katolickiego, który nic nie straci ze swojego autorytetu i wagi, a tego rodzaju synteza będzie mogła stanowić zachętę, by lepiej go zgłębić, a ponadto stanie się jeszcze jednym narzędziem wychowania do wiary"

Opracowanie Kompendium trwało dwa lata i zostało - zgodnie z życzeniem Jana Pawła II - ukończone „we względnie krótkim czasie" ${ }^{\prime \prime}$. Pracą redakcyjną kierował ówczesny prefekt Kongregacji Nauki Wiary kardynał Joseph Ratzinger. Włączyli się w nią także wszyscy kardynałowie i przewodniczący Konferencji Episkopatów. O pracy nad Kompendium Katechizmu Kościoła Katolickiego J. Ratzinger - już jako papież Benedykt XVI - powiedział: „To zadanie mnie przeraziło. Muszę wyznać, że wątpiłem, że coś z tego wyjdzie. Jak bowiem sprawić, żeby autorzy rozproszeni po całym świecie stworzyli razem książkę wartą przeczytania? W jaki sposób ludziom, którzy nie tylko żyją na różnych kontynentach, ale których różni kultura i duchowość, uda się napisać jeden tekst wewnętrznie spójny i zrozumiały dla czytelników w każdym zakątku świata? Ponadto biskupi ci mieli pisać nie jako indywidualni twórcy, lecz wsłuchując się w głos współbraci i Kościołów lokalnych. Muszę wyznać, że plan ostatecznie powiódł się"7.

${ }^{5}$ Jan Paweł II, List do kardynata Josepha Ratzingera, Watykan 2.02.2003, „L'Osservatore Romano" (pol.) 24 (2003) nr 5, s. 27.

${ }^{6}$ Tamże.

7 Benedykt XVI, Wstęp, w: Youcat polski. Katechizm Kościoła Katolickiego dla mtodych, wyd. II popr., Częstochowa 2011, s. 8. 
W Watykanie, 28 czerwca 2005 roku, odbyła się, z udziałem Ojca Świętego Benedykta XVI, uroczysta prezentacja nowego Kompendium Katechizmu Kościoła Katolickiego. W homilii wygłoszonej podczas prezentacji dokumentu papież zwrócił uwagę, że nowe Kompendium stanowi odpowiedź na potrzeby Kościoła, który od momentu opublikowania w 1992 roku Katechizmu Kościoła Katolickiego odczuwał potrzebę „katechizmu bardziej syntetycznego, krótkiego, który zawierałby jedynie wszystkie istotne i fundamentalne elementy wiary i moralności katolickiej, ujęte w prostej formie, dostępnej dla wszystkich, jasnej i zwięzłej" ${ }^{\prime \prime}$. Benedykt XVI podkreślił również, że „Kompendium jest nową formą głoszenia Ewangelii w dzisiejszych czasach", krótko scharakteryzował dokument oraz wyraził wdzięczność wobec autorów, którzy przyczynili się do powstania tak ważnego dzieła ${ }^{9}$. Na zakończenie spotkania papież wręczył egzemplarze Kompendium przedstawicielom zarówno duchowieństwa, jak i wiernych świeckich. Z jego rąk dokument otrzymali: metropolita Wiednia kardynał Christoph Schönborn, sekretarz Kongregacji Nauki Wiary arcybiskup Angelo Amato, kapłan, diakon, zakonnik, zakonnica, rodzina i przedstawiciele młodzieży, dzieci, nauczyciele religii oraz osoba pracująca w duszpasterstwie parafialnym. W ten sposób wyrażona została prawda, że Kompendium przeznaczone jest dla wszystkich, bez względu na wiek czy narodowość.

$\mathrm{W}$ dniu prezentacji dokumentu wydane zostało także Motu proprio Benedykta XVI w sprawie zatwierdzenia i opublikowania Kompendium Katechizmu Kościoła Katolickiego, w którym Ojciec Święty stwierdził: „Kompendium wiernie odzwierciedla strukturę, treść i język Katechizmu Kościota Katolickiego i może stanowić pomoc oraz bodziec do pogłębienia jego znajomości, [...] ze względu na swą zwięzłość, jasność i spójność, może służyć wszystkim ludziom, żyjącym w świecie tak pełnym rozproszeń i rozmaitych przesłań, a pragnącym poznać drogę życia i prawdę, które Bóg powierzył Kościołowi swojego Syna"10.

O znaczeniu i wartości Kompendium Katechizmu Kościoła Katolickiego mówił papież także w czasie niedzielnego rozważania podczas modlitwy Aniot Pański 3 lipca 2005, nazywając je „pożytecznym i praktycznym na-

8 Tenże, Homilia podczas prezentacji Kompendium, Watykan 28.06.2005, „L'Osservatore Romano" (pol.) 26 (2005) nr 9, s. 12.

${ }_{9}$ Por. tamże, s. 13.

${ }^{10}$ Tenże, Motu proprio w sprawie zatwierdzenia $i$ opublikowania Kompendium Katechizmu Kościoła Katolickiego, „L'Osservatore Romano” (pol.) 26 (2005) nr 9, s. 12. 
rzędziem w głoszeniu Chrystusa i jego Ewangelii zbawienia"11. Ponadto w czasie XX Światowego Dnia Młodzieży w Kolonii biskupi przekazali symbolicznie młodzieży Kompendium, a Benedykt XVI zwrócił uwagę na jego znaczenie w poznawaniu wiary Kościoła: „Dlatego tak ważne jest powiedział do młodych - umiłowanie Pisma Świętego, a w konsekwencji znajomość wiary Kościoła, która ukazuje nam sens Pisma. [...] Papież Jan Paweł II dał nam wspaniałe dzieło, w którym wiarę stuleci wyjaśniono w sposób syntetyczny: Katechizm Kościoła Katolickiego. Ja sam mogłem przedstawić niedawno Kompendium tego Katechizmu, przygotowane na życzenie zmarłego Papieża. To dwie fundamentalne książki, które chciałbym wszystkim wam polecić" ${ }^{\prime \prime}$.

We Włoszech Compendio del Catechismo della Chiesa Cattolica przygotowane przez Watykańską Księgarnię Wydawniczą we współpracy z Wydawnictwem Świętego Pawła stało się bestsellerem, osiągając nakład 410 tys. egzemplarzy w pierwszym miesiącu sprzedaży ${ }^{13}$. Podobnie było w Stanach Zjednoczonych, gdzie od marca do lipca 2006 r. sprzedano ponad 125 tys. egzemplarzy ${ }^{14}$.

Troskę o tłumaczenie Kompendium i jego edycję w innych językach powierzono poszczególnym konferencjom biskupów. Wydanie w języku polskim ${ }^{15}$ jest drugim po przekładzie niemieckim (ukazało się 12 sierpnia 2005 r.). Publikacja pojawiła się w Polsce bardzo szybko, bo zaledwie w kilka tygodni po ukazaniu się wersji włoskiej, a nie dwa lata później, jak to było w przypadku polskiego wydania Katechizmu Kościoła Katolickiego. Prezentacja polskiego wydania Kompendium odbyła się 2 września 2005 roku w auli Episkopatu Polski w Warszawie podczas konferencji prasowej, na którą zaproszono między innymi ks. bpa Kazimierza Nycza, ks. prof. Romana Murawskiego oraz przedstawicieli Wydawnictwa Jedność, nakładem którego ukazał się polski przekład.

${ }^{11}$ Tenże, Rozważanie podczas modlitwy Aniot Pański, Watykan 3.08.2005, „Niedziela Tygodnik Katolicki" 40 (2005) nr 29, s. 4.

12 Tenże, Homilia podczas Mszy św. wieńczącej XX Światowe Dni Młodzieży, Kolonia 21.08.2005, „L'Osservatore Romano” (pol.) 26 (2005) nr 10, s. 28.

${ }_{13}$ Zob. https://info.wiara.pl/doc/154394.Kompendium-KKK-po-polsku, dostęp: 24.04.2014.

${ }^{14}$ Zob. http://www.niedziela.pl/artykul/79943/nd/Po-Co-\%E2\%80\%9EKompendium-Katechizmu\%E2\%80\%9D, dostęp: 24.04.2014.

${ }^{15}$ Kompendium Katechizmu Kościoła Katolickiego, tłum. R. Murawski, Kielce 2005. Dalej stosuję skrót: KomKKK. 
Na temat nowo wydanego dokumentu wypowiedzieli się również biskupi polscy zgromadzeni na Jasnej Górze 25 sierpnia 2005 roku: „Biskupi proszą wszystkich wierzących i poszukujących o sięganie po to Kompendium. Niech służy ono poszczególnym wiernym, rodzinom i wspólnotom, katechetom i duszpasterzom. Niech będzie także pomocą $\mathrm{w}$ prowadzeniu katechezy dorosłych w parafiach"16.

\section{STRUKTURA KOMPENDIUM KATECHIZMU KOŚCIOŁA KATOLICKIEGO}

Kompendium Katechizmu Kościoła Katolickiego składa się z 598 pytań i odpowiedzi. W strukturze i w układzie tematycznym jest wiernym odzwierciedleniem 2865 artykułów Katechizmu Kościoła Katolickiego, co stanowi mniej niż L' materiału zasadniczego. Gdy chodzi o objętość stronicową, materiał streszczony w Kompendium (ponad 200 stron tekstu) stanowi $1 / 3$ drugiego wydania Katechizmu Kościota Katolickiego (ponad 700 stron). Kompendium zawiera na wstępie Motu proprio papieża Benedykta XVI oraz wprowadzenie z 20 marca 2005 r., w którym Joseph Ratzinger ówczesny Przewodniczący Komisji Specjalnej podkreśla wielki trud włożony w opracowanie dokumentu oraz wskazuje na trzy podstawowe jego cechy: ścisłą zależność od Katechizmu Kościoła Katolickiego, formę dialogową, użycie obrazów w katechezie ${ }^{17}$.

Struktura Kompendium jest odzwierciedleniem struktury Katechizmu Kościoła Katolickiego i dzieli się na cztery części dotyczące:

- wyznania wiary - lex credendi,

- życia sakramentalnego - lex celebrandi,

- codziennego życia w jedności z Jezusem Chrystusem - lex vivendi,

- modlitwy chrześcijańskiej - lex orandi ${ }^{18}$.

Główny akcent położony został na przedstawienie wyznania wiary (ok. 36\% całego wykładu), co obrazuje poniższa tabela.

${ }^{16}$ Stowo biskupów z Jasnej Góry, Niedziela Tygodnik Katolicki 40 (2005) nr 37, s. 7.

17 Por. J. Ratzinger, Wprowadzenie, w: Kompendium Katechizmu..., s. 10.

${ }^{18}$ Por. tamże. 
Tabela 1: Objętościowa zależność KomKKK od KKK

\begin{tabular}{|c|c|c|c|c|}
\hline \multirow{2}{*}{$\begin{array}{l}\text { Nazwa części } \\
\text { KKK i KomKKK }\end{array}$} & \multicolumn{2}{|c|}{ Katechizm Kościoła Katolickiego } & \multicolumn{2}{|c|}{$\begin{array}{l}\text { Kompendium } \\
\text { Katechizmu Kościoła Katolickiego }\end{array}$} \\
\hline & $\begin{array}{l}\text { numeracja } \\
\text { artykułów }\end{array}$ & $\begin{array}{l}\text { łączna liczba } \\
\text { artykułów } \\
\text { (\% całego KKK) }\end{array}$ & numeracja pytań & $\begin{array}{l}\text { łączna liczba pytań } \\
\text { (\% całego KomKKK) }\end{array}$ \\
\hline Wstęp & $1-25$ & $\begin{array}{c}25 \\
(0,87 \%)\end{array}$ & brak & brak \\
\hline $\begin{array}{l}\text { Część l: } \\
\text { Wyznanie wiary }\end{array}$ & $26-1065$ & $\begin{array}{c}1040 \\
(36,30 \%)\end{array}$ & $1-217$ & $\begin{array}{c}217 \\
(36,29 \%)\end{array}$ \\
\hline $\begin{array}{l}\text { Część ll: } \\
\text { Celebracja misterium } \\
\text { chrześcijańskiego }\end{array}$ & $1066-1690$ & $\begin{array}{c}625 \\
(21,82 \%)\end{array}$ & $218-356$ & $\begin{array}{c}139 \\
(23,24 \%)\end{array}$ \\
\hline $\begin{array}{l}\text { Część III: } \\
\text { Życie w Chrystusie }\end{array}$ & $1691-2557$ & $\begin{array}{c}867 \\
(30,26 \%)\end{array}$ & $357-533$ & $\begin{array}{c}177 \\
(29,60 \%)\end{array}$ \\
\hline $\begin{array}{l}\text { Część IV: } \\
\text { Modlitwa } \\
\text { chrześcijańska }\end{array}$ & $2558-2865$ & $\begin{array}{c}308 \\
(10,75 \%)\end{array}$ & $534-598$ & $\begin{array}{c}65 \\
(10,87)\end{array}$ \\
\hline
\end{tabular}

Tabela wskazuje na ścisłą, objętościową zależność Kompendium od Katechizmu Kościota Katolickiego. Wielkość poszczególnych części Kompendium odpowiada procentowo analogicznym częściom Katechizmu Kościoła Katolickiego. Wyjątek stanowi część druga dotycząca celebracji misterium chrześcijańskiego, która w Kompendium jest o 1,42\% większa aniżeli analogiczna część druga Katechizmu Kościoła Katolickiego.

Kolejnym elementem charakterystycznym dla Kompendium jest forma, w której zostało ono napisane. Forma ta nawiązuje - jak wyjaśnia J. Ratzinger - „do starego, katechetycznego rodzaju literackiego, posługującego się pytaniami i odpowiedziami. [...] idealnego dialogu między nauczycielem i uczniem za pośrednictwem przynaglającej sekwencji pytań, które wciągają czytelnika, zapraszając go do odkrywania ciągle nowych aspektów prawd swojej wiary"19. Forma pytań i odpowiedzi jest nawiązaniem do starych katechizmów, a osobowy wymiar tego dialogu - rozmowy, w której uczeń pyta mistrza, a ten udziela odpowiedzi nawiązaniem do antycznego gatunku literackiego. Zastosowana w Kompendium dialogowa forma przekazu „sprzyja także znacznemu skróceniu tekstu, redukując go do rzeczy istotnych. Może sprzyjać przyswojeniu i ewentualnej memoryzacji treści"20.

19 Tamże, nr 4.

${ }^{20}$ J. Ratzinger, Wprowadzenie, s. 11. Ks. bp Kazimierz Nycz przestrzega jednak 
Trzecim charakterystycznym elementem dokumentu są reprodukcje obrazów, które stanowią pomocny element w katechezie, wskazują na jego zawartość treściową ${ }^{21}$. Spora liczba kolorowych reprodukcji znakomitych obrazów pochodzących ze spuścizny chrześcijańskiej ikonografii, które odpowiadają treści poszczególnych części Kompendium, stanowi ukłon w stronę współczesnej cywilizacji, w której obraz zyskuje przewagę nad słowem. Nawiązuje także do tradycji głoszenia Ewangelii poprzez obraz. „Obrazy sakralne, dzięki swojemu pięknu, zwiastują Ewangelię i promieniują blaskiem katolickiej prawdy, ukazując doskonałą harmonię między dobrem i pięknem, między via veritatis i via pulchritudinis. Są świadectwem wielowiekowej i płodnej tradycji sztuki chrześcijańskiej, a zarazem skłaniają wszystkich, wierzących i niewierzących, aby odkrywali i kontemplowali niewyczerpane piękno tajemnicy Odkupienia, jednocześnie wciąż pobudzają dynamiczny proces jej inkulturacji w rzeczywistości historycznej"22. W Kompendium zamieszczono 15 reprodukcji, a każdą z nich zaopatrzono w komentarz, który objaśnia symbolikę i znaczenie danego obrazu. Są to reprodukcje dzieł mistrzów zachodu, a także ikony bizantyjskie i koptyjskie. Te same ilustracje zostały umieszczone w różnych przekładach Kompendium, co z kolei, jak podkreśla Benedykt XVI, stanowi „czynnik, który pozwala łatwo zidentyfikować i rozpoznać tekst w różnych językach: jedna i ta sama wiara wyznawana jest przez każdego z wiernych w różnorakich kontekstach eklezjalnych i kulturowych"23.

Na końcu Kompendium Katechizmu Kościoła Katolickiego umieszczono dodatek (Apendyks), który zawiera wspólne modlitwy dla Kościoła powszechnego oraz prawdy nauki katolickiej, czyli tzw. mały katechizm: Dwa przykazania miłości; Złotą regułę (Mt 7,12); Osiem błogosławieństw; Cnoty teologiczne; Cnoty kardynalne; Siedem darów Ducha Świętego; Owoce Ducha Świętego; Przykazania kościelne; Uczynki miłosierne co do ciała; Uczynki miłosierne co do duszy; Siedem grzechów głównych; Rzeczy ostateczne. Większość modlitw, zgodnie z życzeniem Ojca Świętego, „w każdej wersji językowej [...] będzie zamieszczona także w języku

przed pamięciowym nauczaniem treści Kompendium: „Byłoby nieporozumieniem, gdyby ktoś próbował tego Kompendium uczyć na pamięć w jakimkolwiek etapie katechezy, nawet w katechezie dorosłych. Jest to niemożliwe", J. Syrek, Vademecum wierzacego człowieka, www.bosko.pl, dostęp: 30.10.2005.

${ }^{21}$ Tamże.

${ }^{22}$ Benedykt XVI, Homilia podczas prezentacji Kompendium, s. 13-14.

${ }^{23}$ Tamże, s. 14. 
łacińskim. Przyswojenie ich sobie również w tym języku ułatwi wspólną modlitwę mówiącym odmiennymi językami, zwłaszcza wówczas, gdy spotykają się z okazji różnych okoliczności"24. Całość zamyka indeks analityczny, zawierający ponad 450 haseł tematycznych, odsyłający do poszczególnych pytań. Znalazły się w nim hasła teologiczne, jak i ogólne - związane z codziennym życia, np. wino, woda, przyjęcie (przyjmowanie), zwierzęta itp.

Materiał w Kompendium przedstawiony został w bardzo przejrzystej formie. Całość dzieli się na cztery zasadnicze części, które dzielą się na działy, a te z kolei na rozdziały. Poszczególne rozdziały zawierają serie ponumerowanych pytań i odpowiedzi. Na marginesach umieszczono numery artykułów Katechizmu Kościoła Katolickiego, do których się one odnoszą. W Kompendium nie ma dolnych przypisów, tak jak to mamy w KKK. Ważniejsze cytaty z Pisma Świętego, Ojców Kościoła, wypowiedzi świętych, wyróżniono, umieszczając je w ramkach na niebieskim tle.

\section{ZASTOSOWANIE KOMPENDIUM KATECHIZMU KOŚCIOŁA KATOLICKIEGO W PODRĘCZNIKACH DO NAUKI RELIGII}

Kompendium Katechizmu Kościota Katolickiego, dar dwóch papieży Jana Pawła II i Benedyka XVI, swoją dialogową formą zachęca do lektury zarówno indywidualnej, jak i wspólnotowej. Można zapytać, na ile ten dar został przyjęty i wykorzystany na szkolnych lekcjach religii? Jaka jest recepcja Kompendium Katechizmu Kościoła Katolickiego we współczesnych podręcznikach do nauki religii dla gimnazjum?

Ramy niniejszego artykuły nie pozwalają na wnikliwą analizę wszystkich podręczników dla młodzieży, dlatego spośród wielu książek wybrano kilka najnowszych i najpopularniejszych w Polsce publikacji adresowanych do młodzieży klas gimnazjalnych. Przeanalizowno je pod kątem wykorzystania - zarówno w podręczniku dla ucznia, jak i w przewodniku metodycznym - cytatów i parafraz z Kompendium Katechizmu Kościoła Katolickiego. Podkreślić należy, że badano wyłącznie wybrane podręczniki do nauczania religii rzymskokatolickiej na terenie całej Polski, wydane po 2010 roku, a więc zgodne z nową Podstawa programowa i nowym Programem nauczania religii.

24 Tamże. 
Już samo ilościowe zestawienie zamieszczone $\mathrm{w}$ poniższej tabeli pokazuje, że daleko jeszcze w polskiej katechezie do recepcji Kompendium, skoro prawie nie pojawia się ono $\mathrm{w}$ podręcznikach do nauki religii.

Tabela 2: Zastosowanie KKK i KomKKK w wybranych podręcznikach do nauki religii w gimnazjum

\begin{tabular}{|c|c|c|c|c|c|}
\hline \multirow{2}{*}{$\begin{array}{c}\text { Autor i tytuł } \\
\text { podręcznika dla ucznia }\end{array}$} & \multirow{2}{*}{$\begin{array}{l}\text { Nr jednostki } \\
\text { lekcyjnej }\end{array}$} & \multicolumn{2}{|c|}{$\begin{array}{c}\text { Katechizm } \\
\text { Kościoła Katolickiego } \\
\text { (nr artykułu) }\end{array}$} & \multicolumn{2}{|c|}{$\begin{array}{c}\text { Kompendium Katechizmu } \\
\text { Kościoła Katolickiego } \\
\text { (nr pytania) }\end{array}$} \\
\hline & & cytat & $\begin{array}{c}\text { parafraza, } \\
\text { odsyłacz }\end{array}$ & cytat & $\begin{array}{c}\text { parafraza, } \\
\text { odsyłacz }\end{array}$ \\
\hline 1 & 2 & 3 & 4 & 5 & 6 \\
\hline $\begin{array}{l}\text { Z. Marek (red.), Jezus uczy i zbawia, } \\
\text { Podręcznik do religii dla I klasy } \\
\text { gimnazjum, } \\
\text { Kraków 2013. }\end{array}$ & & brak & brak & brak & brak \\
\hline $\begin{array}{l}\text { Z. Marek (red.), Jezus działa i zbawia, } \\
\text { Podręcznik do religii dla II klasy } \\
\text { gimnazjum, } \\
\text { Kraków 2013. }\end{array}$ & & brak & brak & brak & brak \\
\hline \multirow{8}{*}{$\begin{array}{l}\text { P. Mąkosa (red.), Spotykam Twoje } \\
\text { Słowo, Podręcznik do religii dla I klasy } \\
\text { gimnazjum, } \\
\text { Lublin } 2012 .\end{array}$} & 2 & 1285 & & 268 & \\
\hline & 3 & 358,1703 & & & \\
\hline & 5 & 1060,1129 & & & \\
\hline & 6 & 136,109 & & & \\
\hline & 9 & $399-402$ & & & \\
\hline & 19 & 1611 & & & \\
\hline & 24 & & 469 & & \\
\hline & 29 & & 691-701 & $389-390$ & \\
\hline $\begin{array}{l}\text { P. Tomasik, Twoje Słowo świattem na } \\
\text { mojej drodze, Podręcznik do nauczania } \\
\text { religii w I klasie gimnazjum, } \\
\text { Warszawa } 2012 .\end{array}$ & & brak & brak & brak & brak \\
\hline \multirow{3}{*}{$\begin{array}{c}\text { J. Szpet, D. Jackowiak (red.), Spotkanie } \\
\text { ze Słowem, Podręcznik do nauki religii } \\
\text { dla pierwszej klasy gimnazjum, } \\
\text { Poznań } 2011 .\end{array}$} & 4 & 1719 & & & \\
\hline & 20 & 27 & & & \\
\hline & 32 & 2571 & & & \\
\hline \multirow{5}{*}{$\begin{array}{c}\text { J. Szpet, D. Jackowiak (red.), Aby nie } \\
\text { ustać w drodze, Podręcznik do nauki } \\
\text { religii dla drugiej klasy gimnazjum, } \\
\text { Poznań } 2012 .\end{array}$} & 1 & 1723 & & & \\
\hline & 4 & $\begin{array}{c}751-752 \\
780\end{array}$ & & & \\
\hline & 6 & $\begin{array}{l}460,464 \\
521 \\
517,655 \\
\end{array}$ & $612-613$ & & \\
\hline & 10 & 1293 & & & \\
\hline & 12 & 1492,1496 & & & \\
\hline
\end{tabular}


Tabela 2: Cd.

\begin{tabular}{|c|c|c|c|c|c|}
\hline 1 & 2 & 3 & 4 & 5 & 6 \\
\hline \multirow{13}{*}{$\begin{array}{c}\text { J. Szpet, D. Jackowiak (red.), Aby nie } \\
\text { ustać w drodze, Podręcznik do nauki } \\
\text { religii dla drugiej klasy gimnazjum, } \\
\text { Poznań } 2012 .\end{array}$} & 14 & 1551 & & & \\
\hline & 16 & 1750 & & & \\
\hline & 17 & 1959 & & & \\
\hline & 19 & 27 & & & \\
\hline & 21 & 1723 & & & \\
\hline & 22 & $\begin{array}{l}1813,1840, \\
2096,2097\end{array}$ & 2095 & & \\
\hline & 23 & 2146 & & & \\
\hline & 27 & 88 & & & \\
\hline & 30 & 2197, 2199 & 2217,2223 & & \\
\hline & 32 & 2284 & & & \\
\hline & 35 & $\begin{array}{c}2469,2487, \\
2505 \\
\end{array}$ & $2464-2486$ & & \\
\hline & 36 & 2520 & 2518,2520 & 533 & \\
\hline & 50 & 1830 & & & \\
\hline \multirow{17}{*}{$\begin{array}{l}\text { W. Kubik (red.), Szukam was, } \\
\text { Podręcznik do religii dla klasy } \\
\text { I gimnazjum, } \\
\text { Kraków } 2011 .\end{array}$} & 7 & & 85 & & \\
\hline & 12 & & & & 76,77 \\
\hline & 17 & & 144-145 & & \\
\hline & 18 & & $60-63$ & & \\
\hline & 31 & & 124 & & \\
\hline & 33 & & 605,622 & & \\
\hline & 35 & & 1018 & & \\
\hline & 36 & & $\begin{array}{c}668,678 \\
679,682, \\
1040\end{array}$ & & \\
\hline & 37 & & $\begin{array}{c}1023,1025 \\
1054\end{array}$ & & \\
\hline & 38 & & 768 & & \\
\hline & 39 & & 857,882 & & \\
\hline & 40 & & $\begin{array}{c}753 \\
754-757 \\
771\end{array}$ & & \\
\hline & 41 & & 2623 & & \\
\hline & 42 & & 782 & & \\
\hline & 43 & & 1881,2070 & & \\
\hline & 44 & & 770,779 & & \\
\hline & 46 & & $6,8,159$ & & \\
\hline
\end{tabular}


Tabela 2: Cd.

\begin{tabular}{|c|c|c|c|c|c|}
\hline 1 & 2 & 3 & 4 & 5 & 6 \\
\hline \multirow{3}{*}{$\begin{array}{l}\text { W. Kubik (red.), Szukam was, } \\
\text { Podręcznik do religii dla klasy } \\
\text { I gimnazjum, } \\
\text { Kraków } 2011 .\end{array}$} & 47 & & 2545,2546 & & \\
\hline & 50 & & $\begin{array}{c}1877,1878 \\
1879\end{array}$ & & \\
\hline & 59 & & 263 & & \\
\hline \multirow{24}{*}{$\begin{array}{c}\text { W. Kubik (red.), Jestem } \\
\text { z wami, Podręcznik do religii dla klasy } \\
\text { Il gimnazjum, } \\
\text { Kraków } 2012 .\end{array}$} & 4 & & 27,30 & & \\
\hline & 5 & & 1879,1936 & & \\
\hline & 6 & & $\begin{array}{c}1878,1880 \\
1882 \\
\end{array}$ & & \\
\hline & 8 & & 777,804 & & \\
\hline & 9 & & & & 190-191 \\
\hline & 16 & & $\begin{array}{c}605,622, \\
1018\end{array}$ & & \\
\hline & 17 & & $659,668,679$ & & \\
\hline & 19 & & 1277,1278 & & \\
\hline & 20 & & 1320 & & 266,268 \\
\hline & 21 & & & & 271,274 \\
\hline & 22 & & & & 292,452 \\
\hline & 24 & & 1531,1532 & & \\
\hline & 26 & & $\begin{array}{c}1546-1553 \\
1592\end{array}$ & & \\
\hline & 27 & & 2456 & & \\
\hline & 39 & & 1674 & & \\
\hline & 43 & & & & $\begin{array}{c}455,459 \\
462\end{array}$ \\
\hline & 45 & & $\begin{array}{c}2392,2394 \\
2395,2396 \\
2397-2398 \\
2373 \\
2400\end{array}$ & & \\
\hline & 46 & 2453 & 2451,2456 & & \\
\hline & 47 & 2284,2464 & $\begin{array}{c}2505,2508 \\
2512\end{array}$ & & \\
\hline & 48 & & $\begin{array}{l}418,2529 \\
2552,2557\end{array}$ & & \\
\hline & 49 & & 2644,2660 & & \\
\hline & 50 & & 2093, 2094 & & \\
\hline & 51 & & 618,2157 & & \\
\hline & 56 & & 820,821 & & \\
\hline
\end{tabular}


Tabela 2: Cd.

\begin{tabular}{|c|c|c|c|c|c|}
\hline 1 & 2 & 3 & 4 & 5 & 6 \\
\hline \multirow{29}{*}{$\begin{array}{l}\text { W. Kubik (red.), Chodźmy razem, } \\
\text { Podręcznik do religii } \\
\text { dla klasy III gimnazjum, } \\
\text { Kraków } 2013 .\end{array}$} & 59 & & 509 & & 562 \\
\hline & 1 & & $27,29,30$ & & \\
\hline & 6 & & $\begin{array}{c}\text { 1829, 1931, } \\
1933\end{array}$ & & \\
\hline & 8 & & $\begin{array}{c}2319,2322, \\
2324\end{array}$ & & \\
\hline & 10 & & & 337 & \\
\hline & 13 & 1317 & $\begin{array}{c}1212,1285 \\
1300\end{array}$ & & \\
\hline & 15 & & 1832,953 & & \\
\hline & 16 & 799 & 800 & & \\
\hline & 19 & 2104 & 2104-2105 & & \\
\hline & 22 & & 527,430 & & \\
\hline & 23 & & 187,194 & & \\
\hline & 24 & & 79 & & 12,13 \\
\hline & 26 & & $142,143,683$ & & \\
\hline & 28 & & & 74 & \\
\hline & 30 & 1864 & 1846,1847 & & \\
\hline & 31 & & & & 108 \\
\hline & 33 & & 809 & & \\
\hline & 35 & 866 & $\begin{array}{c}815,867 \\
830,831 \\
857\end{array}$ & & \\
\hline & 36 & & $814,817,818$ & & \\
\hline & 37 & 8 & 1271 & & \\
\hline & 50 & 2346 & 2518,2342 & & \\
\hline & 51 & & 2302 & & \\
\hline & 53 & & & 60 & \\
\hline & 55 & & 1471 & & \\
\hline & 56 & & 680,681 & & \\
\hline & 58 & & 526 & & \\
\hline & 59 & & 1438 & 299 & \\
\hline & 62 & & $668-669$ & & \\
\hline & 65 & & 478 & & \\
\hline
\end{tabular}


W powyższym zestawieniu uwagę zwraca fakt, że w podręcznikach dla ucznia ${ }^{25}$ pod redakcją Z. Marka nie występuje Katechizm Kościoła Katolickiego oraz jego Kompendium. Wśród wielu cytatów zamieszczonych w podręczniku dla ucznia dominują cytaty biblijne oraz obszerne przedruki z książki M. Wójtowicza Święci z charakterem. Można postawić pytanie o zasadność tak długich cytatów, skoro biogramy świętych są dostępne na licznych stronach internetowych, także jezuickich, na których uczniowie natychmiast i łatwo je odnajdą (trudno dzisiaj znaleźć wśród gimnazjalistów osobę, która nie posiada dostępu do Internetu w telefonie komórkowym, tablecie, laptopie). Także podręczniki pod redakcją P. Tomasika nie wykorzystują Kompendium Katechizmu Kościoła Katolickiego, jak i samego Katechizmu Kościoła Katolickiego. W poradniku metodycznym dla nauczyciela wyodrębniono oddzielną część zatytułowaną Nauczanie Kościoła, jednakże umieszczono $\mathrm{w}$ niej w zasadzie tylko homilie papieskie ${ }^{26}$.

Wśród przeanalizowanych podręczników należy wyróżnić książki pod redakcją W. Kubika. O ile podręczniki ,jezuickie" pod red. Z. Marka nie wykorzystują KKK i KomKKK, to inne - także "jezuickie" - pod red. W. Kubika wielokrotnie wykorzystują oba dokumenty. Niewątpliwie są to nowe książki, nie tylko pod względem okładki i grafiki, ale również treści. Uwagę zwraca troska autorów, aby przybliżyć gimnazjalistom Magisterium Kościoła zawarte w Katechizmie Kościoła Katolickiego i jego Kompendium, a także Youcat - Katechizmie Kościoła Katolickiego dla mtodych. W podręczniku dla ucznia dominuje Katechizm, który jest w wielu miejscach cytowany i parafrazowany. Z kolei w poradniku dla nauczyciela znajdują się nie tylko cytaty z KKK, ale także propozycje zadań do wykonania dla uczniów z zastosowaniem tego dokumentu.

\section{WNIOSKI}

Co kilka lat nauczyciele religii w Polsce otrzymują nową Podstawę programowa i nowy Program nauczania religii. Konsekwencją tych dokumentów jest „wymiana” książek do nauki religii dla uczniów i nauczycieli wszystkich etapów edukacyjnych. Jest to nie tylko duże wyzwanie dla au-

${ }^{25}$ Podobnie jest w przewodnikach metodycznych dla nauczyciela.

${ }^{26}$ Zob. P. Tomasik (red.), Twoje Stowo świattem na mojej drodze, Poradnik metodyczny do nauczania religii w I klasie gimnazjum, Warszawa 2012, s. 120, 152-153, 164-165, 168, 171 (adhortacja), 172 (nota Kongregacji Nauki Wiary). 
torów podręczników, ale również duży wydatek finansowy dla rodziców, których dzieci nie mogą korzystać ze „starych” książek. Taka „wymiana” podręczników to dobra okazja, aby w szkolnym nauczaniu religii znalazły się książki nowe, nie tylko pod względem okładki i grafiki, ale przede wszystkim nowe pod względem treści, a więc uwzględniające najnowsze magisterium Kościoła. Przeprowadzona analiza wybranych podręczników do nauki religii $\mathrm{w}$ gimnazjum pokazała, że jest niestety inaczej. Mimo upływu 9 lat od wydania KomKKK i 20 lat od polskiej publikacji KKK, nadal wielu autorów zdaje się nie dostrzegać tych ważnych dokumentów katechetycznych. Można więc zadać pytanie o zasadność publikacji nowych podręczników do nauki religii? Czym różnią się od tych, które napisano do podstawy programowej z 2001 roku? Co wnoszą nowego? Czy są odpowiedzią na nauczanie papieża Benedykta XVI na temat zastosowania w katechezie KKK i KomKKK? Wydaje się, że tego typu pytania powinni stawiać i na nie odpowiadać przede wszystkim recenzenci pakietów edukacyjnych, bo od ich oceny zależy, jakie podręczniki trafią - na kilka najbliższych lat - do polskich szkół. Katechetów należy z kolei uwrażliwiać na potrzebę wyboru wartościowych publikacji.

Inną sugestię, jaką należałoby skierować do autorów podręczników do nauki religii, to pytanie o zasadność tak licznych w podręcznikach dla ucznia parafraz i cytatów z Katechizmu Kościoła Katolickiego. Geneza KomKKK, jego struktura oraz liczne wypowiedzi papieża Benedykta XVI wyraźnie wskazują, że KKK jest dokumentem - zarówno pod względem struktury, jak i języka - zbyt trudnym dla katechizowanych. Należałoby w książkach dla ucznia częściej umieszczać fragmenty - parafrazy lub cytaty - z Kompendium Katechizmu Kościoła Katolickiego książki, którą uczniowie powinni znać, a której nie posiadają i nie czytają, co więcej zapewne nawet nie słyszeli o tym dokumencie, który jest - jak podkreślał Benedykt XVI - „nową formą głoszenia Ewangelii w dzisiejszych czasach".

Uczniowie na lekcjach religii mogą pracować, indywidualnie lub w grupach, nad tekstem Kompendium, mogą je także czytać w domu. Mogą również oglądać, a także - z pomocą nauczyciela - kontemplować reprodukcje dzieł sztuki zamieszczone w KomKKK. Uczniowie zdolniejsi i mający dostęp ( $\mathrm{w}$ domu lub w bibliotece) do Kompendium mogą przygotowywać pisemne prace np.: Nauczanie Kościoła katolickiego na temat grzechu. Do tego typu pracy mogą wykorzystać Indeks tematyczny zamieszczony na końcu KomKKK. Warto też zachęcić gim- 
nazjalistów do korzystania z tekstów Modlitw wspólnych i Prawd nauki katolickiej ${ }^{27}$, a chętnych do nauczenia się modlitw po łacinie np. Ave, Maria lub Angelus Domini, aby w niedziele móc włączać się w papieską modlitwę Anioł Pański, transmitowaną o godz. 12.00 przez polską telewizję.

Istnieje wiele sposobów wykorzystania Kompendium Katechizmu Kościota Katolickiego. „Stolica Apostolska - jak podkreśla R. Murawski nie wydała żadnych wskazań odnośnie do zastosowania Kompendium. W moim przekonaniu, istnieje kilka wielkich obszarów, w których Kompendium znajdzie szerokie zastosowanie. Stanowić może np. skuteczną pomoc dla wszystkich nauczających prawd wiary, tj. tych, którzy głoszą słowo Boże, katechizują, ewangelizują, niezależnie od tego, w jakich miejscach rozwijają tę działalność. Szybko, łatwo znajdą w nim sformułowaną w sposób krótki i zwięzły oficjalną naukę Kościoła. Określenia podane przez Kompendium mogą okazać się szczególnie przydatne w katechezie młodzieży i dorosłych. Z Kompendium ucieszą się, także z tych samych racji, autorzy i redaktorzy podręczników katechetycznych. Kompendium może być cennym i wartościowym przewodnikiem na drodze wiary dla wszystkich ludzi, zwłaszcza dla dorosłych, nie tylko wierzących, lecz także niewierzących" ${ }^{28}$. Niestety, w Polsce mimo upływu kilku lat od promocji KomKKK, propozycje i sugestie ks. prof. R. Murawskiego nie znalazły praktycznego zastosowania $\mathrm{w}$ szkolnym nauczaniu religii na poziomie gimnazjum.

Streszczenie. Zapomniane „Kompendium”? Artykuł pt. Zapomniane „Kompendium"? składa się z czterech części. W pierwszej autorka przypomina genezę Kompendium Katechizmu Kościoła Katolickiego opublikowanego w 2005 roku, w drugiej krótko charakteryzuje jego strukturę. Część trzecia zawiera wyniki analizy wybranych podręczników do nauki religii dla gimnazjum, przeprowadzonej pod kątem wykorzystania w nich Katechizmu Kościoła Katolickiego i jego Kompendium. W ostatniej autorka postuluje potrzebę recepcji Kompendium w Polsce i podaje sugestie, w jaki sposób wykorzystać je w szkolnym nauczaniu religii.

Słowa kluczowe: Kompendium, Katechizm Kościoła Katolickiego, Benedykt XVI.

${ }^{27}$ Zob. KomKKK, s. 199-217.

${ }^{28}$ Po co "Kompendium Katechizmu”, Z ks. prof. dr. hab. Romanem Murawskim SDB - tłumaczem polskiej wersji „Kompendium Katechizmu Kościoła Katolickiego” - rozmawia Sylwester Skuza, http://www.niedziela.pl/artykul/79943/nd/Po-Co-\%E2\%80\%9EKompendium-Katechizmu\%E2\%80\%9D, dostęp: 12.12.2013. 
Abstract. A Forgotten Compendium? The article entitled, A Forgotten 'Compendium'?, consists of four sections. In section one, Beata Bilicka recalls the roots of the Compendium of the Catechism of the Catholic Church and the reasons that led to it being published in 2005, and section two briefly presents the main points of its content. Section three of the article lays out the results of an analysis of selected religious textbooks used in the gymnasium (junior high school), which are examined in the light of their use of the CCC and the Compendium. Finally in section four, the author addresses the need for the proper reception of the Compendium in Poland, giving some suggestions as to how it might be used in school catechesis.

Keywords: Compendium, Catechism of the Catholic Church, Benedict XVI. 